Article

\title{
Beef Cattle Farms' Conversion to the Organic System. Recommendations for Success in the Face of Future Changes in a Global Context
}

\begin{abstract}
Alfredo J. Escribano
Independent Researcher and Consultant, C/Rafael Alberti 24, Cáceres 10005, Spain; alessa04@alumnos.unex.es or ajescc@gmail.com; Tel.: +34-617-908-400

Academic Editor: Sean Clark

Received: 27 March 2016; Accepted: 13 June 2016; Published: 18 June 2016

Abstract: Dehesa is a remarkable agroforestry system, which needs the implementation of sustainable production systems in order to reduce its deterioration. Moreover, its livestock farms need to adapt to a new global market context. As a response, the organic livestock sector has expanded not only globally but also in the region in search for increased overall sustainability. However, conversions to the organic system have been commonly carried out without analyzing farms' feasibility to do so. This analysis is necessary before implementing any new production system in order to reduce both the diversity of externalities that the variety of contexts leads to and the vulnerability of the DDehesa ecosystem to small management changes. Within this context and in the face of this gap in knowledge, the present paper analyzes the ease of such conversions and the farms' chances of success after conversion in the face of global changes (market and politics). Different aspects ("areas of action") were studied and integrated within the Global Conversion Index (GCI), and the legal requirement for European organic farming, organic principles, future challenges for ruminants' production systems, as well as the lines of action for the post-2013 CAP (Common Agricultural Policy) and their impacts on the beef cattle sector were taken into account. Results revealed that farms must introduce significant changes before initiating the conversion process, since they had very low scores on the GCI $(42.74 \%)$, especially with regard to health and agro-ecosystem management (principle of Ecology). Regarding rearing and animal welfare (principle of justice/fairness), farms were close to the organic system. From the social point of view, active participation in manufacturing and marketing of products should be increased.
\end{abstract}

Keywords: Mediterranean; drylands; agroecology

\section{Introduction}

Organic livestock production has increased substantially in recent years in order to both increase farmers' income (trough agricultural subsidies and higher sale prices) and reduce farms' environmental impact. Moreover, the potential role of organic production in the socio-economic development of rural areas has been claimed by development agencies and has contributed to this trend.

In the region under study (Extremadura, SW Spain), the Dehesa ecosystem is a remarkable agroforestry system where small changes in farms' management can lead to important changes in both farm and agro-ecosystem sustainability. However, Dehesa farms' low economic performance has induced farmers to make adaptive changes, some of which (mainly intensification) have lead to reductions in the sustainability of both the Dehesa ecosystem and its livestock farms. One of the most recent adaptive changes has been the transition to the organic production system. The regional organic livestock sector is mainly composed of beef cattle, and was the fourth most important with regard to the number of this species and productive orientation (98 beef cattle farms, 5.63\% of farms) [1] in 2014. 
As part of the Mediterranean area, Dehesa benefits from the well-known ruminant pasture-based production systems. In this sense, the organic system apparently fits within this system's characteristics. In fact, Nardone et al. (2004) [2] predicted good feasibility of the conversion process towards the organic system in such an area.

In general terms, such transition has usually been carried out without plans of action in most cases. However, it is necessary to precisely assess such feasibility before implementing any new production systems (especially in sensitive ecosystems such as the Dehesa), since the diversity of contexts among countries and farms is too great to generalize assumptions and carry out business model changes based on them. The reason for this is that these transitions can be very variable, as they depend on several factors, i.e., national regulations, certification bodies, the production system and the livestock species [3]. Thus, both positive and negative effects have been observed in cattle farms. For instance, productivity is often reduced and production costs increased, mainly during the first years of transition and due to the higher cost of organic feedstuff $[4,5]$.

Thus, previous to the conversion, an in-depth study of the sector must be carried out, detecting its external and internal factors (SWOT: Strengths Weaknesses Opportunities and Threats Analysis), paying special attention to its future challenges on the basis of political, market and climatic changes. Thereby, it will be possible to predict the difficulties that farms will go through during the conversion process and establish tailor-made guidelines for each farm (or group of farms) in order to shape successful and sustainable business. Hence, it will finally be possible to design not only organic production systems but also sustainable ones in both local and global contexts.

In accordance, the present study aims to: (i) assess the feasibility of conversion of a sample of pasture-based beef cattle farms to a optimal production system designed not only on the basis of the organic regulation but also on its principles, taking into account future challenges for ruminants' production systems, as well as the lines of action for the post-2013 CAP (Common Agricultural Policy) and their impacts on the beef cattle sector; and (ii) establish specific measures to ease the conversion process and increase farms' chances of success after conversion is accomplished.

\section{Materials and Methods}

\subsection{Study Area}

The study area was the DDehesa ecosystem located in the Extremadura region (Spain). This region presents annual mean temperatures ranging between 16 and $17^{\circ} \mathrm{C}$. Summers are dry and hot (the mean temperature in July is over $26{ }^{\circ} \mathrm{C}$, and the maximum is usually over $40{ }^{\circ} \mathrm{C}$ ). Annual rainfalls are irregular during the year and also among years. The mean rainfall varies between $300 \mathrm{~mm}$ and $800 \mathrm{~mm}$. Extremadura is located in SW Spain (between latitude $37^{\circ} 56^{\prime} 32^{\prime \prime}-40^{\circ} 29^{\prime} 15^{\prime \prime}$ and longitude $\left.4^{\circ} 38^{\prime} 52^{\prime \prime}-7^{\circ} 32^{\prime} 3^{\prime \prime}\right)$ and constitutes the core (geographically and in terms of hectares) of the Dehesa (Figure 1), grouping 2.2 million hectares from the 3 million hectare total area of Dehesa. This ecosystem is the most widely-used agroforestry system in Europe, and has been considered as a habitat to be protected under the European Habitats Directive, the cornerstone of Europe's nature conservation policy [6]. In it, trees, cereal-legume crops and extensive low-input farming systems based on grazing are integrated, where cork, firewood, hunting, and birdwatching, are also common and economically important. Soils are poor and, because of its continental Mediterranean climate, supply of grazing resources is scarce and irregular [7].

Livestock production systems have a great impact on overall sustainability in disfavored and/or sensitive areas (socially, economically and environmentally), which is even higher in traditional (extensive and mixed) production systems. In particular, Dehesa's traditional animal production systems were commonly diverse (mixed), where a mixture of agricultural uses (various livestock species-mainly beef, crops for animal feeding, hunting, and forestry) could be found. 


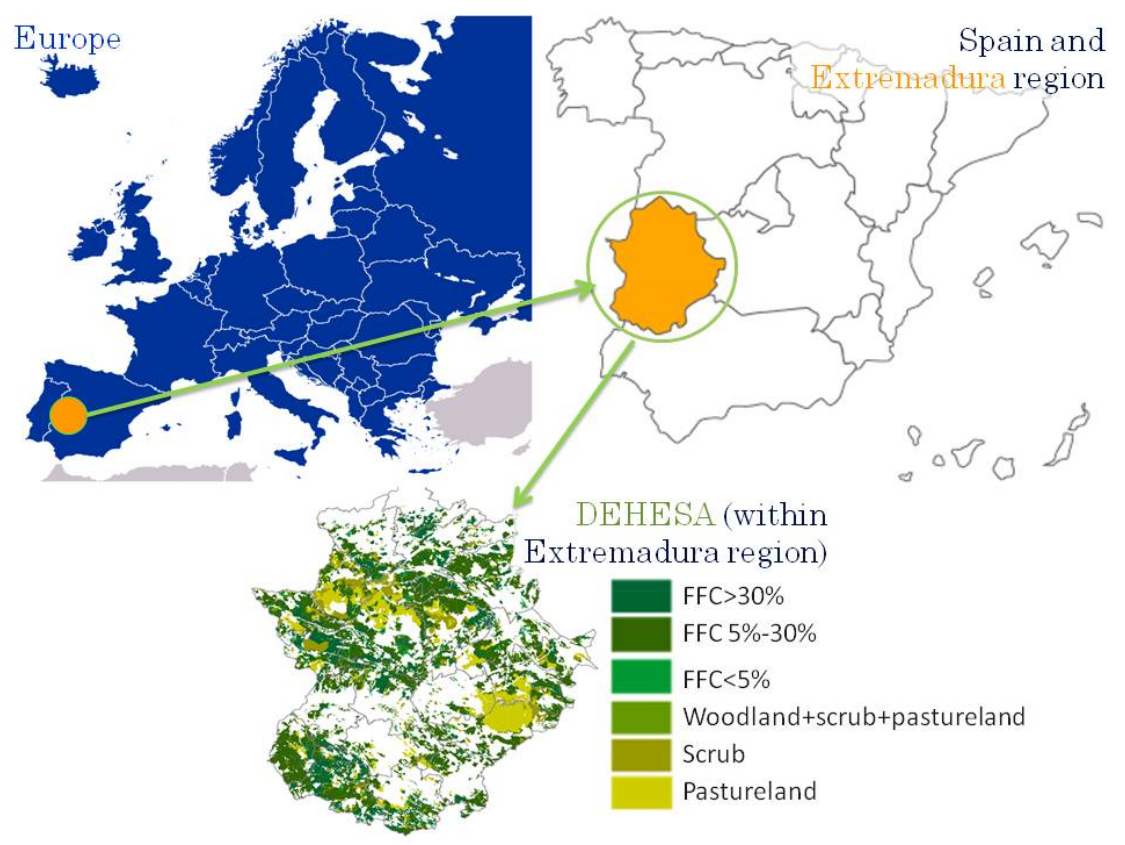

Figure 1. Dehesa location and different land cover characteristics. FFC (Forest Fractional Cover): Fraction of the land covered by the vertical projection of the tops of trees.

From an economic point of view, the importance of the livestock sector in Extremadura is reflected by its contribution to the Agrarian Production in the region. In 2010, cattle, swine and small ruminants sectors generated (in terms of meat and livestock) a total of 629.52 million Euros at basic prices in Extremadura, which accounted for $32.23 \%$ of the regional Agrarian Production. If the products (milk and wool) are included, this value amounts to $€ 396.46 \mathrm{M}$, reaching $36.10 \%$ [8].

From a social point of view, it is noteworthy to highlight that, in semiarid and rural regions such as Extremadura and Dehesa, extensive livestock production systems are often the main activity [9], and even the only source of livelihood [10]. In the case of Extremadura, the contribution of the livestock sector to the regional employment in 2010 was well above the national value $(11.2 \%$ of the working population in Extremadura were related to the agricultural sector, while in Spain only $4.4 \%$ were in agricultural employment) [11]. Such dependence on the sector highlights the need to protect it and enhance it, as it contributes to create jobs, increase income and sustain the rural population, which is vital for the economy and rural development of these areas [12-15].

From a cultural and environmental perspective, traditional production systems are crucial for the conservation of cultural heritage and local identity, as well as landscape [16] and habitats of high ecological and aesthetic value $[17,18]$. This has its rationale in the fact that the Dehesa agro-ecosystem is an evolution of the original Mediterranean woodland by human activity in order to carry out agricultural activities. These production systems contribute to the improvement of soil and pastures, ensure biodiversity, and control coppice and woody scrub regrowth, thus reducing the risk of wildfire [3].

Different socioeconomic factors have led to abandonment and intensification processes that endanger the conservation of such traditional systems and the sustainability of the area in terms of three main pillars of sustainability (society, economy and environment), so that the evaluation and search for sustainable production systems are needed.

\subsection{Farms Selection}

Due to a lack of official statistics about figures and location of Dehesa farms in Extremadura, the sampling was nonprobabilistic by quotas. Forestry, livestock production, and farm size criteria were used to select the farms with the aim of obtaining a representative sample of the various subsystems of 
Dehesa, following the methodology used by previous studies [19-21]. The number of farms surveyed was 30, which is in accordance with other research studies on the topic (24 farms [22]; 31 farms [23,24]). More detailed information on these criteria can be found in the previous study of Escribano [3].

\section{Sample Characterization: Conventional Farms}

The sector located in the area under study is characterized by its scarce use of external feed resources (only for covering adults' maintenance nutritional requirements during summer). In most cases, calves are sold at weaning and fattened in feedlots, so that the value added to the farm is usually scarce. Moreover, cows' reproductive performance (weaned calves/cow/year) is low (0.81). All this reduces their income, bargaining power and competitiveness. To compensate for this situation, an important part of the farmer's activities is to carry out other economic activities that reduce economic risk and increase adaptation to sectorial changes [25].

Specifically, the farms analyzed had an average size of 275.80 ha of Utilized Agricultural Area (UAA), of which $64 \%$ was owned. Nearly $50 \%$ of it was covered by woody species, which has environmental, cultural and economic relevance. However, the presence of crops is almost non-existent, which increases farms' exposure to unstable and scarce on-farm feed resources. Average herd size reached 111.70 adult animals, of which $98 \%$ where cattle (adult cows and bulls). Total stocking rate was extremely high for the ecosystem under study (0.73 Livestock Units/ha), which suggests the necessity to lead Dehesa cattle production systems back.

Regarding management and herds' structure, it is notable that the use of reproductive techniques is typically scarce (estrus synchronization was only carried out in the $6.70 \%$ of farms; the same values as for implementation of artificial insemination). Genetically, farms were mainly composed of Purebred autochthonous cows (20.11\% of total cows) and Purebred foreign bulls $(86.98 \%)$.

\subsection{Selection of Indicators}

First, a literature review was carried out, based on the European legal requirements for organic beef cattle production [27] and subsequent amendments), as well as the principles of organic production set by IFOAM [26]. Requirements and principles were transformed into indicators.

Subsequently, other indicators that were considered important for the study were selected from the literature on the topic $[21,22,25,28-30]$. Furthermore, future political context and challenges for ruminants' production systems under extensive conditions in drylands were taken into account, as were the pillars and lines of action for the post-2013 CAP, and the impacts of the CAP on beef cattle sector [20,31]. In general terms, the 2014-2020 CAP has changed its philosophy, so that it is nowadays not only focused on ensuring the income of a certain segment of the population, but also on promoting the development of territories, promoting the efficient use of resources with an eye on a sustainable and diverse agricultural sector, paying even more attention on rural areas [32]. Thus, the challenges of "The CAP towards 2020" are the following: economics, food security, price volatility, and the agricultural sector's environmental impact (greenhouse gases, soil degradation, pollution, habitats and biodiversity). To do this, CAP has renewed instruments based on three main pillars (competitiveness, environmental sustainability, and rural development), where agri-food value chain (transparent and fair) and risk management are notable aspects and changes of the reform. Such instruments are as follows: market measures (reducing risks and improving risk management), agri-food value chain (fairness and transparency), research and knowledge transfer.

Although the boundaries of the system were the farm, some aspects of the food chain upstream (kilometers travelled by fodder) and downstream (products processing products by the producer, and direct sales) were also included, due to the importance of these aspects for the sustainability of these farms [33]. Finally, a list of 55 indicators (Table 1), complying with the criteria of relevance, practicability, and end user value recommended by [34] were selected. Then, aiming to increase the practical applicability of the results of the present study, indicators were grouped into "areas of action". 
Table 1. Indicators selected.

\begin{tabular}{|c|c|c|c|c|c|c|}
\hline $\begin{array}{c}\text { Conversion Indicators and Areas } \\
\text { of Action }\end{array}$ & Definitions and Units & Dummy & $\begin{array}{l}\text { Optimal } \\
\text { Value }\end{array}$ & Criteria $^{1}$ & Principle $^{2}$ & $\begin{array}{l}\text { Weight } \\
(\%)\end{array}$ \\
\hline $\begin{array}{l}\text { Organic concentrate to } \\
\text { fattening calves }\end{array}$ & $\begin{array}{l}\text { Fattening calves were given } \\
\text { organic concentrates. }\end{array}$ & Yes & 1 & Comp. & & \\
\hline Organic fodder to fattening calves & $\begin{array}{l}\text { Fattening calves were given organic } \\
\text { fodder/grass. }\end{array}$ & Yes & 1 & Comp. & & \\
\hline Organic concentrate to adults & $\begin{array}{l}\text { Cows and bulls were given organic } \\
\text { concentrates. }\end{array}$ & Yes & 1 & Comp. & & \\
\hline Organic fodder to adults & $\begin{array}{l}\text { Cows and bulls were given organic } \\
\text { fodder/grass. }\end{array}$ & Yes & 1 & Comp. & & \\
\hline Ration 60:40 & $\begin{array}{l}\text { At least } 60 \% \text { of daily ration was based on } \\
\text { common forage and/or grass. }\end{array}$ & Yes & 1 & Comp. & & \\
\hline Feed management & & & & & 1,2 & 21.68 \\
\hline $\begin{array}{l}\text { Number of veterinary medicines } \\
\text { to calves }\end{array}$ & $\begin{array}{l}\text { Calves (younger than one year) do not receive } \\
\text { more than } 1 \text { treatment. }\end{array}$ & Yes & 1 & Comp. & & \\
\hline $\begin{array}{l}\text { Number of veterinary medicines } \\
\text { to adults }\end{array}$ & $\begin{array}{l}\text { Adults neither receive more than } 3 \text { veterinary } \\
\text { medicines nor } 2 \text { antiparasitics per year. }\end{array}$ & Yes & 1 & Comp. & & \\
\hline Preventive antiparasitics & $\begin{array}{l}\text { The farmer did not use antiparasitics } \\
\text { systematically as a preventive health } \\
\text { management practice. }\end{array}$ & Yes & 1 & Comp. & & \\
\hline Preventive antibiotics & $\begin{array}{l}\text { The farmer did not use antibiotics } \\
\text { systematically as a preventive health } \\
\text { management practice. }\end{array}$ & Yes & 1 & Comp. & & \\
\hline Healthy herd & The herd was healthy. & Yes & 1 & Comp. & & \\
\hline Cleaning products & $\begin{array}{l}\text { Products used to clean the infrastructure were } \\
\text { allowed by the Council Regulation. }\end{array}$ & Yes & 1 & Comp. & & \\
\hline Isolating for health reasons & $\begin{array}{l}\text { Livestock was isolated when they were } \\
\text { suffering infectious diseases easily contagious. }\end{array}$ & Yes & 1 & Comp. & & \\
\hline Quarantine & $\begin{array}{l}\text { Livestock were isolated when coming from } \\
\text { other farms. }\end{array}$ & Yes & 1 & Comp. & & \\
\hline
\end{tabular}


Table 1. Cont

\begin{tabular}{|c|c|c|c|c|c|c|}
\hline $\begin{array}{c}\text { Conversion Indicators and Areas } \\
\text { of Action }\end{array}$ & Definitions and Units & Dummy & $\begin{array}{l}\text { Optimal } \\
\text { Value }\end{array}$ & Criteria $^{1}$ & Principle $^{2}$ & $\begin{array}{l}\text { Weight } \\
(\%)\end{array}$ \\
\hline Alternative medicine & $\begin{array}{l}\text { The farmer used phytotherapy } \\
\text { and/or homeopathy. }\end{array}$ & Yes & 1 & Comp. & & \\
\hline Water quality assessment & Water quality was assessed at least annually. & Yes & 1 & Comp. & & \\
\hline Vaccines & $\begin{array}{l}\text { The farmer did not use of vaccines for } \\
\text { non-endemic illnesses. }\end{array}$ & Yes & 1 & Comp. & & \\
\hline Health Management & & & & & $1,3,2$ & 20.83 \\
\hline Calves access to open spaces & Calves have permanent access to open spaces. & Yes & 1 & Comp. & & \\
\hline Adults access to open spaces & Adults have permanent access to open spaces. & Yes & 1 & Comp. & & \\
\hline Infrastructure (meters and facilities) & $\begin{array}{l}\text { The infrastructure was adequate with regard } \\
\text { to the meters and facilities needed for organic } \\
\text { beef farms. }\end{array}$ & Yes & 1 & Comp. & & \\
\hline Calving period & $\begin{array}{l}\text { The calving period was adequately organized } \\
\text { in order to make better use of the available } \\
\text { natural resources. }\end{array}$ & Yes & 1 & Comp. & & \\
\hline Infrastructure (cleanness) & $\begin{array}{l}\text { The infrastructure was adequate with regard } \\
\text { to cleanness. }\end{array}$ & Yes & 1 & Comp. & & \\
\hline Fattening period length & $\begin{array}{l}\text { It was less than } 3 \text { months and less than } 1 / 5 \text { of } \\
\text { their lifespan. }\end{array}$ & Yes & 1 & Comp. & & \\
\hline Protection against bad weather & $\begin{array}{l}\text { The infrastructure has protection against } \\
\text { sunlight, heat, raining, etc. }\end{array}$ & Yes & 1 & Comp. & & \\
\hline Weaning age & The lactation period lasted at least 3 months. & Yes & 1 & Comp. & & \\
\hline Isolating/Tying & $\begin{array}{l}\text { Livestock was not isolated and/or tied up for } \\
\text { reasons that were not related to } \\
\text { health management. }\end{array}$ & Yes & 1 & Comp. & & \\
\hline Mutilations & The farmer does not carry out mutilations. & Yes & 1 & Comp. & & \\
\hline
\end{tabular}


Table 1. Cont.

\begin{tabular}{|c|c|c|c|c|c|c|}
\hline $\begin{array}{l}\text { Conversion Indicators and Areas } \\
\text { of Action }\end{array}$ & Definitions and Units & Dummy & $\begin{array}{l}\text { Optimal } \\
\text { Value }\end{array}$ & Criteria $^{1}$ & Principle $^{2}$ & $\begin{array}{l}\text { Weight } \\
(\%)\end{array}$ \\
\hline Autochthonous bovine breeds & $\begin{array}{l}75 \% \text { or more of the cattle was autochthonous } \\
\text { or considered as such in the region } \\
\text { under study. }\end{array}$ & Yes & 1 & Comp. & & \\
\hline Animal welfare training & $\begin{array}{l}\text { The farmer has attended to animal } \\
\text { welfare courses. }\end{array}$ & Yes & 1 & Comp. & & \\
\hline Rearing and Animal Welfare & & & & & 4,1 & 9.17 \\
\hline Stocking rate & Livestock Units/ha. & No & $0.33-0.5$ & Rec. & & \\
\hline Use of pesticides and/or herbicides & $\begin{array}{l}\text { The farmer did not use pesticides } \\
\text { and/or herbicides. }\end{array}$ & Yes & 1 & Comp. & & \\
\hline Use of mineral fertilizers & The farmer did not use mineral fertilizers. & Yes & 1 & Comp. & & \\
\hline Rotational grazing & $\begin{array}{l}\text { Grazing was organized so that all plots were } \\
\text { not grazed continuously. }\end{array}$ & Yes & 1 & Comp. & & \\
\hline$\%$ of wooded area & Wooded area/total area. & No & 1.00 & Max. & & \\
\hline Dung management & $\begin{array}{l}\text { Qualitative scale }(0-3) .0 \text { : There was no dung } \\
\text { accumulation due to extensification; } 1 \text { : No } \\
\text { heaping, then spreading of immature dung; } \\
\text { 2: There was some heaping (not enough), so } \\
\text { that dung was not spread completely mature; } \\
\text { 3: Proper compost elaboration, and spreading. }\end{array}$ & No & 0 and 3 & Rec. & & \\
\hline Legumes & $\begin{array}{l}\text { Dichotomic. O: No. 1: Yes. Legumes were } \\
\text { planted in isolation or associated with grains. }\end{array}$ & Yes & 1 & Max. & & \\
\hline Reforestation & $\begin{array}{l}\text { Dichotomic. O: No. 1: Yes. The farmer plant } \\
\text { autochthonous trees. }\end{array}$ & Yes & 1 & Max. & & \\
\hline Reduced tillage & $\begin{array}{l}\text { Dichotomic. O: No. 1: Yes. Reduced or } \\
\text { no-tillage agriculture was practiced. }\end{array}$ & Yes & 1 & Max. & & \\
\hline Crop rotation & $\begin{array}{l}\text { Dichotomic. O: No. 1: Yes. The farmer } \\
\text { practices fallow, crop rotation, etc. }\end{array}$ & Yes & 1 & Max. & & \\
\hline Crop association/Intercropping & $\begin{array}{l}\text { Dichotomic. O: No. 1: Yes. The farmer } \\
\text { practices crop associations/intercropping. }\end{array}$ & Yes & 1 & Max. & & \\
\hline Cover crops & $\begin{array}{l}\text { Dichotomic. O: No. 1: Yes. The farmer used } \\
\text { cover crops. }\end{array}$ & Yes & 1 & Max. & & \\
\hline
\end{tabular}


Table 1. Cont.

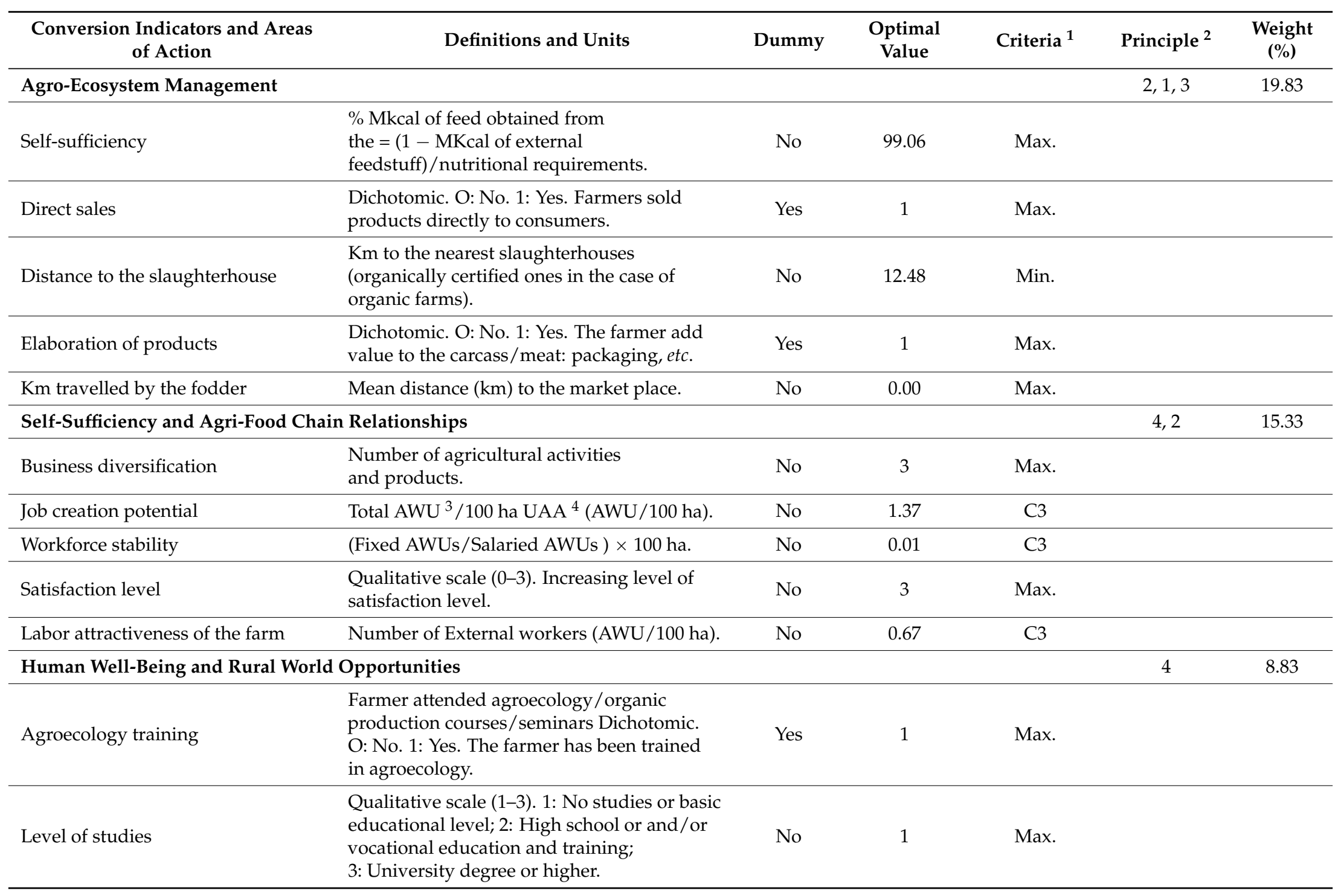


Table 1. Cont.

\begin{tabular}{|c|c|c|c|c|c|c|}
\hline $\begin{array}{c}\text { Conversion Indicators and Areas } \\
\text { of Action }\end{array}$ & Definitions and Units & Dummy & $\begin{array}{l}\text { Optimal } \\
\text { Value }\end{array}$ & Criteria $^{1}$ & Principle $^{2}$ & $\begin{array}{l}\text { Weight } \\
(\%)\end{array}$ \\
\hline Farmer' age & Years. & No & 30 & Rec. & & \\
\hline Data registering & $\begin{array}{l}\text { Dichotomic. O: No. 1: Yes. Farmer records } \\
\text { technical and economic data. }\end{array}$ & Yes & 1 & Max. & & \\
\hline Continuity/Future plans & $\begin{array}{l}\text { Qualitative scale (1-4).1: Abandon; } 2 \text { : Herd } \\
\text { reduction or change of species; } 3 \text { : Maintain } \\
\text { specie(s) reared and herd size; } 4 \text { : Increase the } \\
\text { herd size. }\end{array}$ & No & 3 and 4 & Max. & & \\
\hline \multicolumn{5}{|c|}{ Human Capability Towards Implementing Sustainable Agricultural Practices } & 4 & 4.33 \\
\hline
\end{tabular}




\subsection{Ordination of Indicators in Areas of Action, Allocation of Optimal Values and Relative Weights}

After this process, optimum values were established for each indicator in accordance with stakeholders' and experts' opinions. Due to the fact that most of the indicators were created on the basis of organic regulations and principles, and/or on specific agro-ecological practices, most of these indicators were dummy or binomial (Table 1 provides detailed information in this regard), and their optimal value was 1 , indicating "compliance". Hence, each variable acquired a mutually exclusive and unique value with a binomial Bernoulli distribution. In the case of quantitative indicators, the optimal values were established following the procedure of previous studies $[8,35,36]$, where the author's previous experience and the characteristics of the sample were taken into account.

Finally, relative weights were attributed to each area of action, so that each Partial Conversion Index (PCI) had a different contribution to the GCI. The relative weighting of the areas of action is a recommended process as it allows aspects (areas) of greater impact on the ease of conversion and farms future success to be prioritized. Following the methodology of participatory research used by [25], numerical weights were established in a focus group meeting. This allowed the integration of local and scientific knowledge, taking into account participants' knowledge and values, following a collaborative procedure. Each participant was provided with a list of relative weights. Thus, the sum of the relative weights of each indicator of the same attribute will be equal to $100 \%$. Their mean value corresponds to the final relative weight.

The selection of indicators and the establishment of the relative weights was based on the following criteria: (i) areas of action's importance with regard to compliance with the European regulations on organic production; (ii) principles of organic production and sustainability dimensions (mainly social and environmental); and (iii) farms' internal and external factors, as well as their future challenges in relation with predicted changes on agricultural policies and market. This allowed indicators to be derived, measured, and monitored as part of a systemic, participatory, interdisciplinary, and flexible process of evaluation.

The complete list of indicators of conversion, the principle they belong to, the areas of action in which they were included, and the relative weights of such areas are presented in Table 1.

\subsection{Calculation of Conversion Index: Individual Conversion Scores, Partial Conversion Index (PCI) and Global Conversion Index (GCI)}

There are previous studies that have analyzed the feasibility of conversion of farms to organic or agro-ecological production systems $[22,28-30,37]$. However, the above-mentioned methodology allows not only assess the feasibility of conversion to the organic system set by European regulations and the principles of organic production, but also addresses important issues and challenges for the analyzed farms (SWOT and future challenges).

In order to apply this broader approach, methodological adaptations have been carried out. Such adaptations integrated the Organic Livestock Proximity Index developed by [29], the MESMIS Framework [38], and the AMOEBA approach [39]. MESMIS Framework (Framework for the Evaluation of Management Systems incorporating Sustainability Index) has been widely used through years to assess livestock systems' sustainability [40]. This methodology, along with the AMOEBA approach [39], allows the selection of indicators and their transformation on scores based on optimal values for each indicator, so that their initial values of the indicators are converted to percentage values (scores) according to their proximity to the optimum value. Thus, $100 \%$ is the optimal/desirable value. Thus, farms with several indicators with values of $100 \%$ in each area, would be more easily converted to organic. This analysis would generate the limit (maximum desirable value) for each area of action. To do this, three possible cases are faced: 
(1) When the indicators have an optimum value corresponding to either the maximum value of the sample or the value 1 for the case of qualitative variables, the scores were calculated as follows (Equation (1)):

$$
\text { Individual conversion score }=(\text { initial value of the indicator/optimal value }) \times 100
$$

(2) However, for indicators whose optimal value was the minimum value found in the sample (i.e., distance traveled by feed), the scores were calculated as follows (Equation (2)):

$$
\text { Individual conversion score }=(\text { optimal value } / \text { initial value of the indicator }) \times 100
$$

(3) When optimum values were percentiles (range of values) or recommended values (such as farmer's age), the formula applied depended upon the magnitude of the indicator values and their optimal value. If the value of the indicator was lower than the optimum value, the Equation (1) was applied. In contrast, when the indicator value was higher than the optimal value, Equation (2) was applied. Moreover, for certain indicators, more details must be taken into account. Thus, in cases such as that of total stocking rate, either exceeding or not reaching the optimal value penalized the farm, since both high and low values lead to ecosystem degradation. In other variables (i.e., self-sufficiency), the value of individual conversion scores remained $100 \%$ although the indicator value is greater than the optimum value. This allows for conversion rates for each indicator as the production systems are studied.

The next step is to calculate the conversion of each area of action (Partial Conversion Index: PCI). It was calculated as the average of the individual conversion scores grouped within the area of action.

$$
\mathrm{PCI}=\text { mean of individual conversion scores }
$$

Finally, the GCI was the summation of multiplying each PCI by its relative weight.

$$
\mathrm{GCI}=\Sigma \mathrm{PCI} \times \text { relative weight }
$$

At this point, it is necessary to point out that any value was established as a threshold to decide whether farms could be converted to the organic system or not. The present study and methodological approach allowed increasing the understanding of the farms and make decisions regarding the conversion process based on the integrated study of all indicators and areas of action, taking into account the context of each of the farms (including the predicted global context changes mentioned in the introduction section). Moreover, conversion is justified if the recommendations and comments included in the discussion section are taken into account. After this, a reevaluation of the farms should be carried out and then the decision on conversion would be made again.

\subsection{Statistical Analysis of Results}

Once the PCI were obtained, farms were grouped based on them. For this purpose, a hierarchical cluster analysis (CA) using Ward's method and squared Euclidean distance was applied. Input variables for the $\mathrm{CA}$ were the $\mathrm{PCI}$ of the seven action areas. They were standardized by standard deviation. The CA allowed reducing the number of individual cases (farms) to a smaller (clusters or farms typologies), thus maximizing homogeneity within each typology and heterogeneity among them [41]. This facilitated the understanding of the farms involved in the study, since by means of an in-depth analysis, farm typologies' key features were identified. Then, it was possible to define measures for facilitating the conversion process and farms' success once issues were overcome. 
Later, differences among farms' typologies were detected with regard to individual conversion scores and GCI. To do so, a single factor or one-way ANOVA was applied. Statistical analyses were carried out with the 2011 Statistical Package for Social Systems, version 20.0 [42]. The complete methodological procedure and steps can be observed schematically in Figure 2. It shows how different aspects (both the requirements for a ruminant production operation and other parameters of relevance for the sustainability of the sector under study) to be considered organic were converted into a checklist.

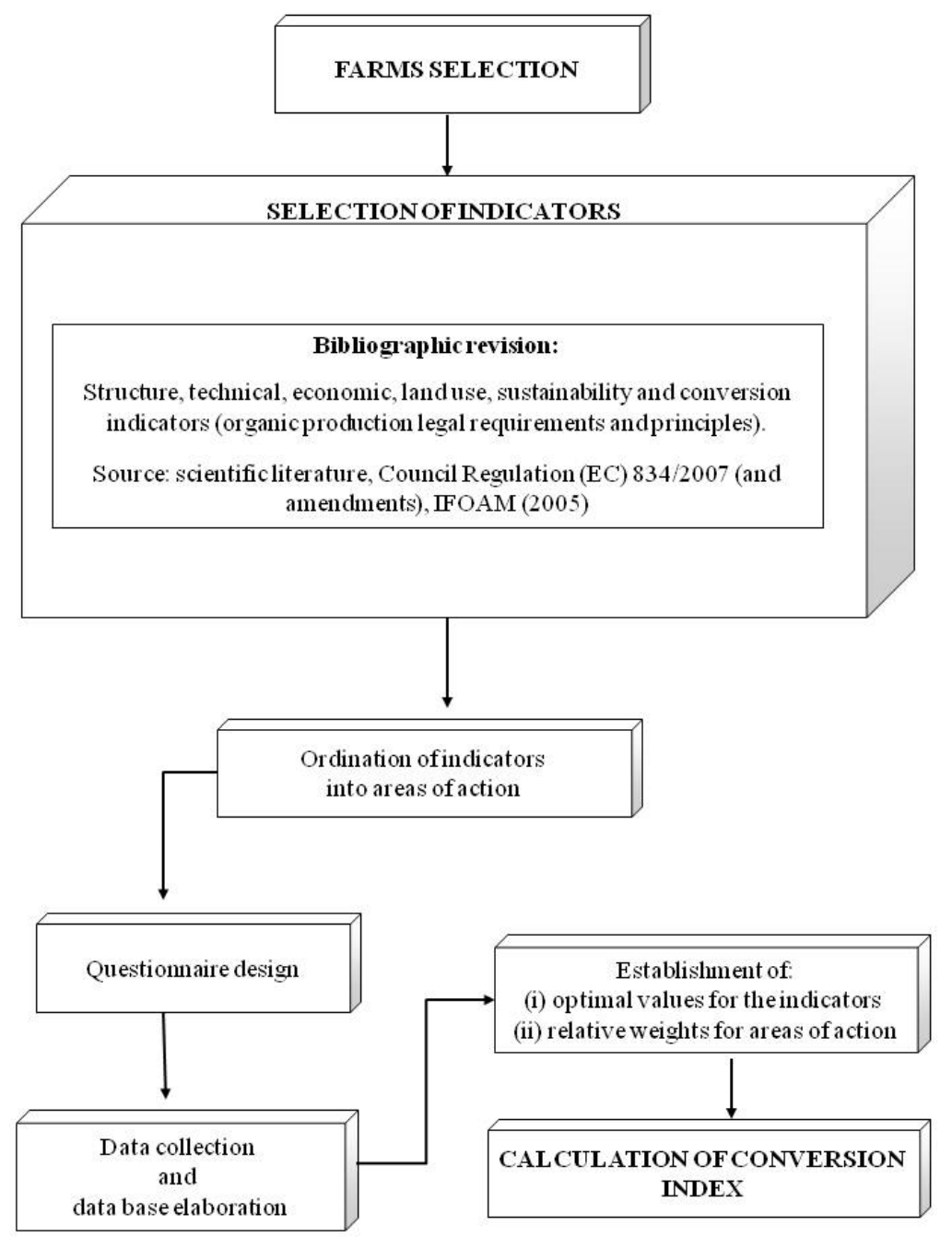

Figure 2. Process followed from the farms selection step to the calculation of conversion indexes.

\section{Results}

First, individual conversion scores for each indicator are shown (Tables 2-4).

Later, PCI and GCI scores are shown according to farms typologies (Table 5). The CA yielded the most significant results for a four-cluster solution (a better explanation thereof). The linkage distance used was in line with that of other studies on the topic [43], with a relatively short distance $(<20 \%)$. The resulting dendrogram is presented in Figure 3. The clusters (typologies) obtained from the CA were compared using an analysis of variance. For a better understanding of the characteristics of each typology, Table 5 is provided, showing the average values, standard error and significance level of the typologies regarding both the PCI and GCI. Figure 4 facilitates the comprehension regarding sample's partial scores (PCIs). 
Table 2. Farms' scores with regard to cattle management. Areas of action: Feed Management, Health Management, and Rearing and Animal Welfare.

\begin{tabular}{|c|c|c|c|}
\hline Areas of Action & Indicators & Sample Mean (\%) & SE \\
\hline \multirow{5}{*}{ Feed Management } & Organic concentrate to fattening calves & 00.00 & 00.00 \\
\hline & Organic fodder to fattening calves & 00.00 & 00.00 \\
\hline & Organic concentrate to adults & 00.00 & 00.00 \\
\hline & Organic fodder to adults & 00.00 & 00.00 \\
\hline & Ration 60:40 & 83.33 & 6.92 \\
\hline \multirow{11}{*}{ Health Management } & Number of veterinary medicines to calves & 90.00 & 5.57 \\
\hline & Number of veterinary medicines to adults & 93.33 & 4.63 \\
\hline & Preventive antiparasitics & 3.33 & 3.33 \\
\hline & Preventive antibiotics & 73.33 & 8.21 \\
\hline & Healthy herd & 100.00 & 0.00 \\
\hline & Cleaning products & 20.00 & 7.43 \\
\hline & Isolating for health reasons & 90.00 & 5.57 \\
\hline & Quarantine & 46.67 & 9.26 \\
\hline & Alternative medicine & 0.00 & 0.00 \\
\hline & Water quality assessment & 33.33 & 8.75 \\
\hline & Vaccines & 100.00 & 0.00 \\
\hline \multirow{12}{*}{$\begin{array}{c}\text { Rearing and Animal } \\
\text { Welfare }\end{array}$} & Calves access to open spaces & 100.00 & 0.00 \\
\hline & Adults access to open spaces & 100.00 & 0.00 \\
\hline & Infrastructure (meters and facilities) & 0.00 & 0.00 \\
\hline & Calving period & 33.33 & 8.75 \\
\hline & Infrastructure (cleanness) & 100.00 & 0.00 \\
\hline & Fattening period length & 83.33 & 6.92 \\
\hline & Protection against bad weather & 43.33 & 9.20 \\
\hline & Weaning age & 96.67 & 3.33 \\
\hline & Isolating/Tying & 100.00 & 0.00 \\
\hline & Mutilations & 100.00 & 0.00 \\
\hline & Autochthonous bovine breeds & 13.33 & 6.31 \\
\hline & Animal welfare training & 93.33 & 4.63 \\
\hline
\end{tabular}

SE: Standard error.

Table 3. Farms' scores with regard to agro-ecosystem management. Area of action: Agro-ecosystem management.

\begin{tabular}{clcc}
\hline Area of Action & \multicolumn{1}{c}{ Indicators } & Sample Mean (\%) & SE \\
\hline & Stocking rate & 61.47 & 4.60 \\
& Use of pesticides and/or herbicides & 73.33 & 8.21 \\
& Use of mineral fertilizers & 63.33 & 8.95 \\
& Rotational grazing & 4.67 & 0.93 \\
& \% of wooded area & 45.55 & 7.92 \\
Agro-Ecosystem & Dung management ${ }^{1}$ & 28.33 & 6.65 \\
Management & Legumes & 10.00 & 5.57 \\
& Reforestation & 0.00 & 0.00 \\
& Reduced tillage & 50.00 & 9.28 \\
& Crop rotation & 10.00 & 5.57 \\
& Crop association/Intercropping & 0.00 & 0.00 \\
& Cover crops & 6.67 & 4.63 \\
\hline
\end{tabular}

SE: Standard error. ${ }^{1}$ Number of measures/agricultural management practices implemented to reduce soil erosion and to improve soil quality. These include: cover crops, mulching, intercropping, crop rotation, plot rotation, fallow, and use of compost. 
Table 4. Farms' scores with regard to social aspects. Areas of action: Self-sufficiency and agri-food chain relationships, Human well-being and rural world opportunities, and Human Capability towards Implementing Sustainable Agricultural Practices.

\begin{tabular}{|c|c|c|c|}
\hline Area of Action & Indicators & Sample Mean (\%) & SE \\
\hline \multirow{5}{*}{$\begin{array}{l}\text { Self-Sufficiency and } \\
\text { Agri-Foodchain } \\
\text { Relationships }\end{array}$} & Self-sufficiency & 65.18 & 4.80 \\
\hline & Direct sales & 0.00 & 0.00 \\
\hline & Distance to the slaughterhouse & 88.18 & 1.84 \\
\hline & Elaboration of products & 0.00 & 0.00 \\
\hline & Km travelled by the fodder & 95.36 & 1.43 \\
\hline \multirow{5}{*}{$\begin{array}{l}\text { Human Well-Being and } \\
\text { Rural World Opportunities }\end{array}$} & Business diversification & 38.89 & 2.81 \\
\hline & Job creation potential & 43.64 & 3.83 \\
\hline & Workforce stability & 10.00 & 5.57 \\
\hline & Satisfaction level & 52.87 & 3.77 \\
\hline & Labor attractiveness of the farm & 23.94 & 6.37 \\
\hline \multirow{5}{*}{$\begin{array}{l}\text { Human Capability Towards } \\
\text { Implementing Sustainable } \\
\text { Agricultural Practices }\end{array}$} & Agroecology training & 26.67 & 8.21 \\
\hline & Level of studies & 70.00 & 5.14 \\
\hline & Farmer' age & 68.29 & 2.99 \\
\hline & Data registering & 66.67 & 8.75 \\
\hline & Future plans & 85.67 & 4.57 \\
\hline
\end{tabular}

SE: Standard error.

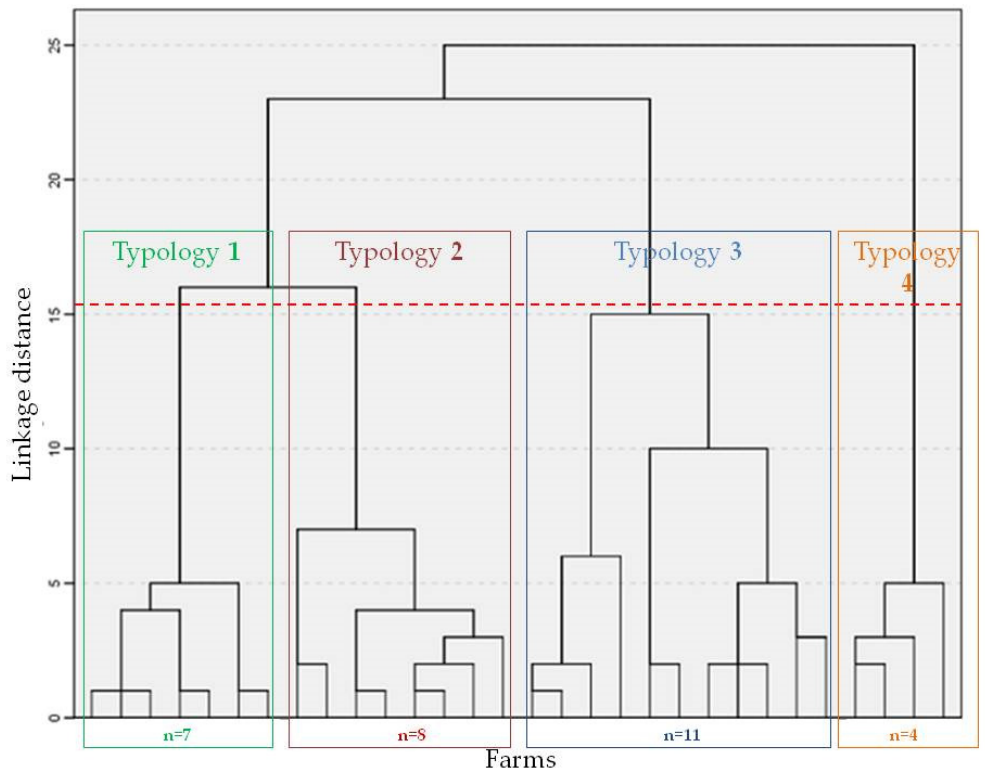

Figure 3. Dendrogram: Hierarchical cluster analysis of farms using Ward's method and the squared Euclidean distance.

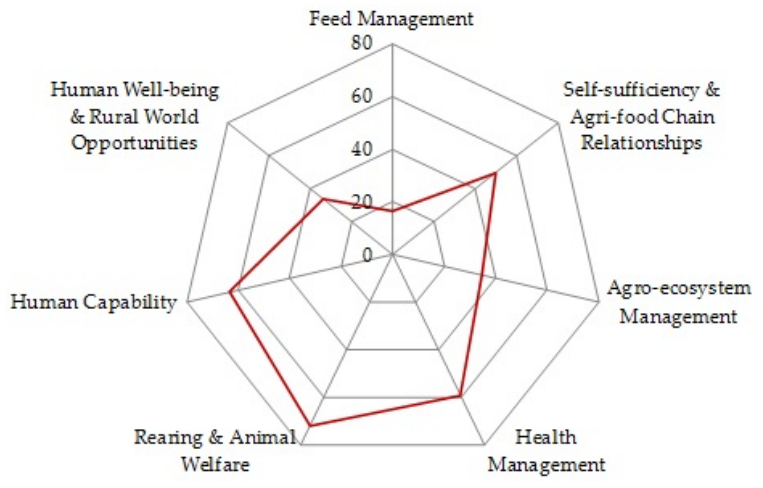

Figure 4. GCI scores of the farms. 
Table 5. Partial Conversion Indices (PCIs) and Global Conversion Index (GCI). Mean scores and standard error for farm typologies and sample.

\begin{tabular}{|c|c|c|c|c|c|c|}
\hline \multirow[b]{2}{*}{$\begin{array}{l}\text { Conversion Index and Areas } \\
\text { of Action }\end{array}$} & \multicolumn{5}{|c|}{ Mean $( \pm$ SE) } & \multirow[b]{2}{*}{ F; sig. } \\
\hline & T1 $(n=7)$ & T2 $(n=8)$ & T3 $(n=11)$ & $\mathrm{T} 4(n=4)$ & $\begin{array}{l}\text { Sample of Conventional } \\
\text { Farms }(n=30)\end{array}$ & \\
\hline Feed Management & $20.00 \mathrm{a}( \pm 0.00)$ & $20.00 \mathrm{a}( \pm 0.00)$ & $18.18 \mathrm{a}( \pm 1.82)$ & $0.00 \mathrm{~b}( \pm 0.00)$ & $16.67( \pm 1.38)$ & $31.06 ; 0.000$ \\
\hline Health Management & $57.15 b( \pm 1.68)$ & $54.55 b( \pm 1.72)$ & $66.12 \mathrm{a}( \pm 1.77)$ & $52.28 \mathrm{~b}( \pm 2.28)$ & $59.09( \pm 1.36)$ & $11.55 ; 0.000$ \\
\hline Rearing and Animal Welfare & $76.19 b( \pm 1.19)$ & $75.00 \mathrm{a}( \pm 1.57)$ & $68.94 a( \pm 1.98)$ & $66.67 \mathrm{a}( \pm 3.40)$ & $71.94( \pm 1.16)$ & $4.65 ; 0.010$ \\
\hline Agro-Ecosystem Management & $18.59 \mathrm{~b}( \pm 3.37)$ & $46.76 \mathrm{a}( \pm 3.09)$ & $34.73 a( \pm 3.15)$ & $37.67 \mathrm{a}( \pm 6.72)$ & $34.56( \pm 2.55)$ & $9.87 ; 0.000$ \\
\hline $\begin{array}{l}\text { Self-Sufficiency and Agri-Food } \\
\text { Chain Relationships }\end{array}$ & $51.85 \mathrm{ab}( \pm 1.08)$ & $53.14 \mathrm{~b}( \pm 1.54)$ & 47.27a ( \pm 1.99$)$ & $46.06 a( \pm 2.65)$ & $49.74( \pm 1.04)$ & $3.04 ; 0.047$ \\
\hline $\begin{array}{l}\text { Human Well-Being and Rural } \\
\text { World Opportunities }\end{array}$ & $23.96 b( \pm 2.18)$ & $32.21 \mathrm{a}( \pm 2.97)$ & $43.78 \mathrm{a}( \pm 5.29)$ & $27.27 \mathrm{ab}( \pm 3.04)$ & $33.87( \pm 2.59)$ & $4.38 ; 0.013$ \\
\hline $\begin{array}{l}\text { Human Capability Towards } \\
\text { Implementing Sustainable } \\
\text { Agricultural Practices }\end{array}$ & $54.45 \mathrm{ab}( \pm 6.63)$ & $78.53 b( \pm 7.33)$ & $64.74 \mathrm{ab}( \pm 4.91)$ & $45.55 a( \pm 7.84)$ & $63.46( \pm 3.70)$ & $3.88 ; 0.020$ \\
\hline Global Conversion Index & $39.34 \mathrm{~b}( \pm 1.10)$ & $46.24 \mathrm{a}( \pm 1.08)$ & $44.84 \mathrm{a}( \pm 0.85)$ & $35.92 b( \pm 1.20)$ & $42.74( \pm 0.85)$ & $16.82 ; 0.000$ \\
\hline
\end{tabular}

Notes: SE (Standard Error); F: F-score; Sig.: level of significance. 
Farms' Typologies: PCI and GCI Scores

Typologies 3 (36.67\% of the sample) and 1 (23.33\%) obtained intermediate $(44.84 \%$ and $39.34 \%$, respectively) GCI scores. Typology 1 stands out for two reasons: (i) health management was very close to that required in organic production; and (ii) it made a high contribution to human well-being and rural world opportunities. With regard to T1, it is worth mentioning their farming methods with regard to rearing and animal welfare. This typology also showed the highest scores (along with T2) with respect to Feed management, which was due to an adequate 60:40 (forage:concentrate) ratio.

$\mathrm{T} 4$, consisted of $13.33 \%$ of farms in the sample had the lowest scores in terms of the GCI (35.92\%), and for almost all areas of action. T2 (26.67\% of farms) scored the highest for most areas of action (feed management, agro-ecosystem management, self-sufficiency, agri-food chain relationships, and human capability towards implementing sustainable agricultural practices), and for the GCI (46.24\%).

\section{Discussion}

The GCI shows the proximity and feasibility of converting conventional Dehesa beef cattle farms to the organic system (Table 5). Moreover, the study according to areas of action has allowed observing the areas in which farms would find less difficulty in carrying out the conversion. Therefore, the conversion process would require major changes in this regard. Regarding a practical application and the decision, it should be based on the areas of action and specific indicators of conversion, so that the farmers can reduce the weaknesses of each system, providing solutions and specific improvement measures.

\subsection{Feed Management}

As shown in Table 2, farms had low scores in terms of feed management because all farms analyzed were conventional ones so they did not provide organic feed.

\subsection{Health Management}

The fact that Dehesa beef cattle farms are extensive and that the local climate is hot and dry, means that veterinary actions are limited. In this sense, it could be expected that the conversion process is simple from the health management perspective. However, it has been observed that in the conventional farms analyzed, health management systematically (either there are clinical signs of illness or not) relies on the use of 1 or 2 antiparasitic products as a preventive measure. Moreover, calves entering the fattening period receive antibiotic treatments in order to prevent disorders typically related to this period (diarrheas and pneumonia). These findings are noteworthy because of their impacts in terms of public health (antibiotic resistance) and environmental pollution. Therefore, aiming to avoid such negative implications of the current health management, and in order to be consistent with the organic methods, farm health management should be based on preventive health management. As land is commonly not a limitation in Dehesa farms, this could be done by establishing grazing plan transitions: (i) prevent access to flooded areas (almost non-existent); (ii) reserve ungrazed plots for young animals; and (iii) integrate other non-host species of parasites, so that parasitic load is reduced. In addition, the level of stocking rates must be reduced in some farms.

Regarding the use of cleaning products, farms had low scores, so farmers should change the products used to disinfect and clean the facilities, which will not be complicated since [44] allows for the use of common commercial products used in many conventional farms.

The use of alternative medicine products was non-existent. Due to the lack of knowledge and commercially available products, health management must be based on grazing management, stocking rates and agro-ecosystem management practices oriented to increase microbiota competition (i.e., intercropping, cropping diversity, habitat maintenance, etc.). Fortunately, Dehesa extensive production systems, its climate and the diversity within farms allow for this management, and additional health measures will not be necessary. 
Therefore, in general it can be said that the Dehesa beef cattle farms could easily convert to the organic system in terms of livestock health management. However, it is necessary that these farms reduce the systematic (not necessary) use of preventive of antiparasitics (mainly in summer for ticks) and antibiotics at the start of the fattening period.

\subsection{Rearing and Animal Welfare}

Overall, farms had high scores (71.94\%) for this area of action. Low scores were only observed regarding the degree of protection against bad weather and on the presence of autochthonous breeds. The low scores for proper infrastructure were due to the absence of facilities in cattle farms (more than to the lack of them), which is in turn due to the extensiveness on the system and the low number of farms fattening animals. In fat farms, fattening animals used to be done in plots (instead of feedlots). Infrastructures were clean enough, non-therapeutic mutilations were not common, and animals were isolated only for health purposes. Overall, animal welfare requirements are not apparently a major concern to convert the farms that were analyzed.

\subsection{Agro-Ecosystem Management}

As shown in Table 3, farms obtained poor scores (34.56\%) on this area of action. This was mainly due to the use of pesticides/herbicides and of mineral fertilizers in many farms. These products are prohibited by Council Regulation (EC) No. 834/2007 ([27] and amendments), so that these farms should stop using them in order to be organic. This would not be difficult since crops are rainfed and their destination is livestock direct feeding (farmers are not looking to produce high amounts of highly priced crops).

However, regarding self-sufficiency, it must be mentioned that there is a remarkable decoupling between livestock and agriculture (previously observed in the Mediterranean area by Dantsis et al. [45]). This integration is important due to the interactions between livestock and plant-soil interface, and the low self-reliance of the farms (low purchasing power to buy external feed). Moreover, the use of protective-conservative agri-environmental practices is almost non-existent. Their implementation is important due to the fragility of the ecosystem. They would allow: (1) minimizing the disturbance; (2) maximizing soil surface; and (3) stimulating biological activity. This would allow better use of resources, increase ecosystem services, the landscape value and carbon sequestration, thus increasing long-term ecosystem's functionality, as well as its stability, economic performance and sustainability $[46,47]$. Although they are not mandatory, they are in accordance with IFOAM principles and agricultural sustainability, so that they should be implemented. Here, farmers would find great difficulties, since their application requires major changes such as training producers and designing production systems.

\subsection{Self-Sufficiency and Agri-Food Chain Relationships}

Despite the importance of self-reliance in pasture-based livestock systems [43], farms have shown low scores in this sense. This has been identified as one of the major weaknesses to convert to the organic system in the Mediterranean area [2,22]. As mentioned in the previous section, crop area should be increased and feed should be conserved for shortage periods. This is even more important if the higher price of organic feedstuff is taken into account. Agricultural business management out of the farm gate (to add value to the products and direct marketing) is essential for livestock production, even more in added value foods, so that farmers receive a higher price for their products. This has been identified as one of the main factors that determine the profitability of organic farms $[4,33,48-50]$. Moreover, these practices increase social interaction, opportunities in the rural world and the social and environmental impact of the food chain upstream. In the farms studied, direct sales by producers (a practice that is often linked to the organic sector), was nonexistent. This is still common and is due to the high resources (financial and human) required. This is even more remarkable in the livestock sector, since the perishable nature of fresh meat and hygiene regulations make it difficult and expensive due 
to cooling and logistics costs, even more if one takes into account that the main markets in terms of sales are mainly located in foreign countries (Figure 5); thus, the domestic market development is a challenge. To successfully overcome this barrier, producers must also focus on the European market, where consumption per capita is high (Figure 6), despite country sales being lower). Moreover, the low development of the organic industry as well as the low demand for organic meat products would hinder the transition to the organic system [3].

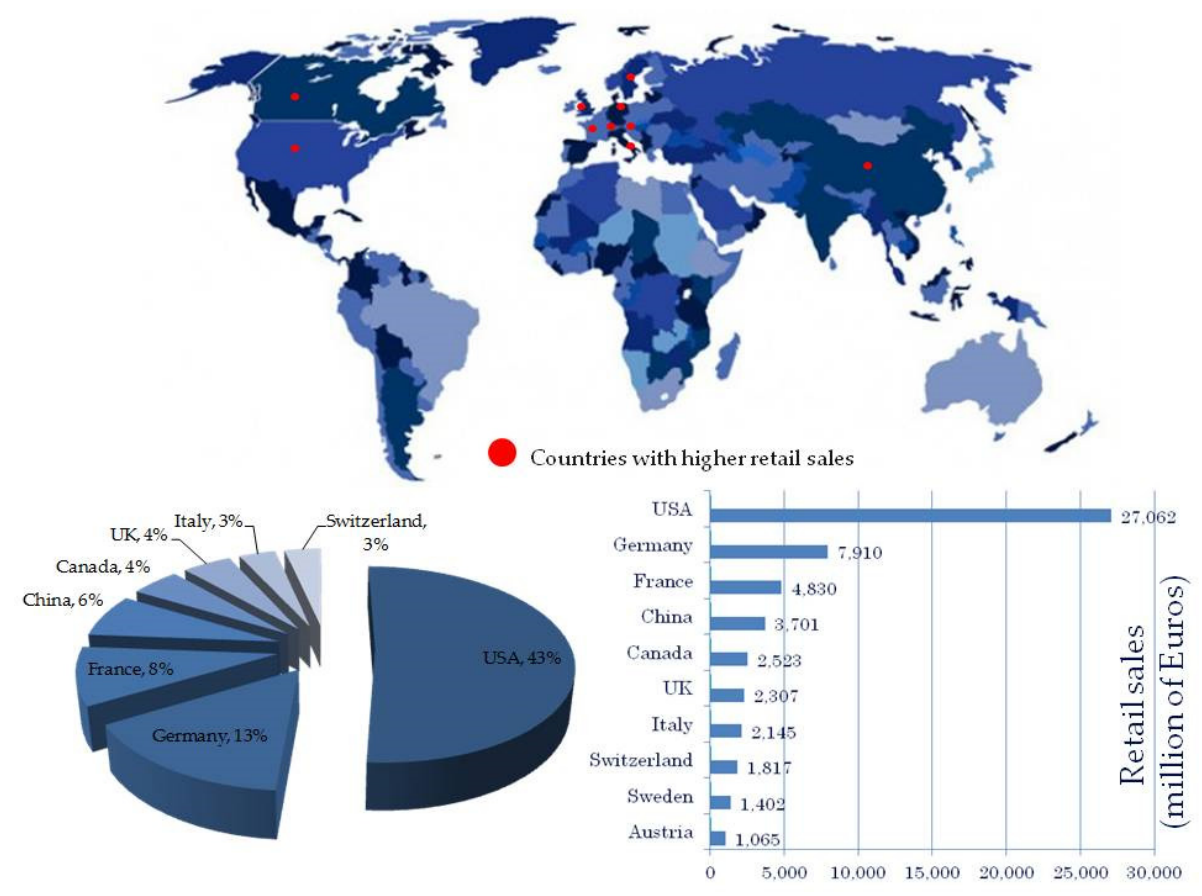

Figure 5. Countries with the largest markets for organic food. Retail sales: Million Euros. Upper map: (C)TrueMiltra-FreeVectors.com. Charts: Own elaboration from FIBL (2016) [51].

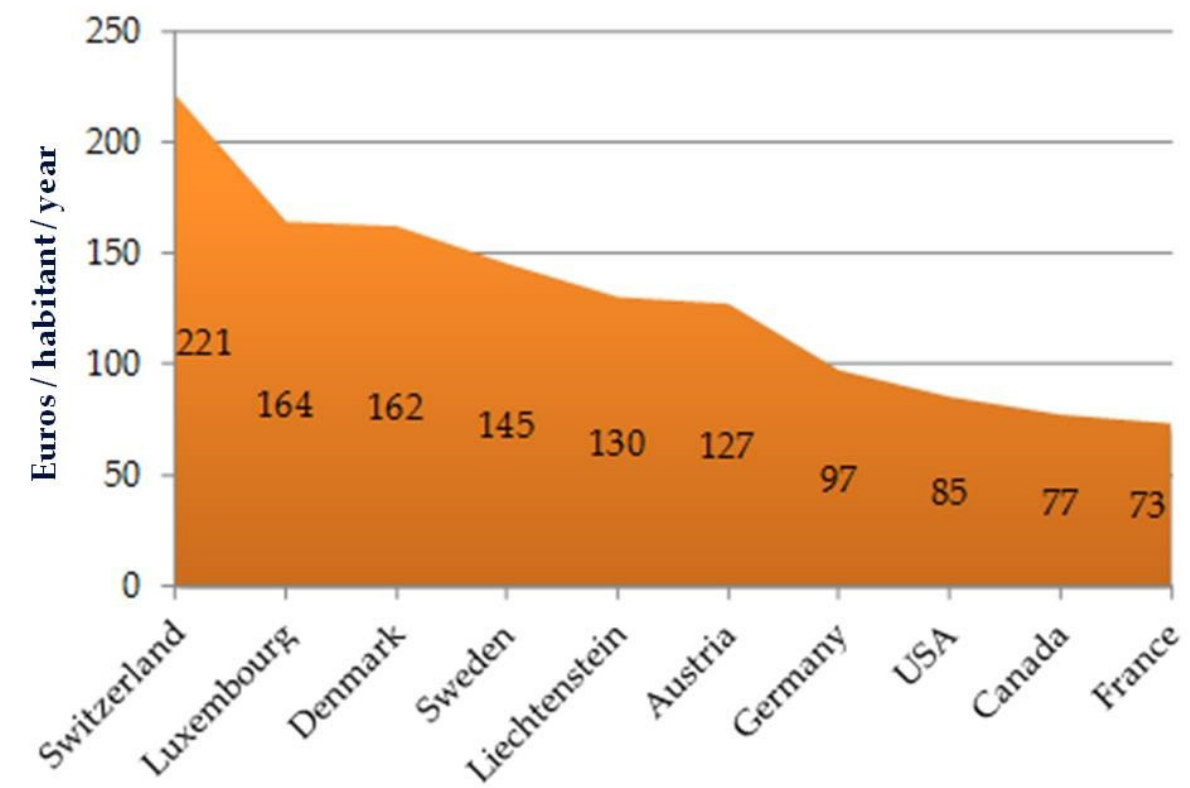

Figure 6. Countries with the highest per capita consumption (euros/habitant/year) in 2014. Own elaboration from FIBL (2016) [51]. 


\subsection{Human Well-Being and Rural World Opportunities}

This area of action is closely related to the principle of fairness, sustainable development and the food chain (above discussed). The study of this area is particularly important on farms and the ecosystem under study, due to the interdependent triad among the pasture, rural populations and livestock. In this regard, farms must improve their degree of business diversification, the number of jobs created and their stability (these are the main factors that both attract and retain people in rural areas). In general terms, conversion can be positive regarding job creation [52].

\subsection{Human Capability towards Implementing Sustainable Agricultural Practices}

This area of action allowed understanding farmers' level of knowledge regarding organic production systems, their willingness to adopt them (farmers' age and future plans), and their adaptability to manage them. Farmers obtained low scores partially due to lack of interest (motivation) to find new sustainable business models in the face of future global changes (market and agricultural policies). Also, the lack of formal training on the field contributed negatively. As a recommendation, consulting and training initiatives through extension services, as well as trade unions and agricultural organizations must be enhanced [3].

Fortunately, the similarity between conventional and organic extensive pasture systems allows providing a process of simple conversion. However, the implementation of organic systems requires increased training, especially in business and agro-environmental terms.

\subsection{Other Aspects Worthy of Discussion: Barriers, Perspectives and Solutions}

It is worth mentioning the relationship between the results obtained and farms future sustainability. In this sense, the farms were classified with regard to different organic principles that are interrelated with sustainability dimensions. Farms' classification based on cluster analysis has allowed having a deeper understanding of farms' group (typology) situations with regard to sustainability dimensions.

In this sense, T2 scored the highest in terms of Agro-ecosystem management (which is related to environmental sustainability). Regarding social sustainability, T2 showed higher results for self-sufficiency and agri-food chain relationships, while T3 had higher scores for human well-being and rural world opportunities. In terms of human resources/capital, T2 stood out from the rest. In general terms, it has been observed that most of the farmers did not focus on sustainability (social dimension: animal welfare, human health, creation of jobs; environmental dimension: environmental protection; economic dimension: local economy, short marketing channels). One of the main reasons for this has been the fact that many farms could easily comply with the organic regulations without carrying out environmentally-friendly management practices in their agro-ecosystems. Therefore, there is a real need for increasing managers' level of knowledge in the sustainability of agricultural practices. Special attention has not been paid to animal welfare, which could also be due to the fact that it is commonly assumed that animals under extensive production systems have a higher welfare status.

In order to implement such aspects, income plays a more important role than farmers' motivations, thus environmental quality and welfare status should be awarded and or supported (either via price premium and consumer's awareness, or agricultural subsidies). The review of Escribano [3] paid due attention to the market side because it was identified as key. However, marketing of organic animal products is not simple, since national demand is low, which requires export (and consequently a higher level of knowledge and costs) (Figures 5 and 6).

Regarding livestock management, there is a need to design feeding strategies that provide adequate nutrition, which is important to ensure a high level of health status based on prevention. From the economic viewpoint, feed management must be more focused on local resources in order to avoid the high costs of external organic feedstuff. This also has a consequence on the environmental side (nutrient cycling). Moreover, regulations should both unify criteria and facilitate the production 
of feed additives by companies because the consequences of it could be really important and positive for the organic livestock sector and for the sustainability of the food system.

Animal health in organic farming constitutes a challenge in many areas. Fortunately, due to the climate in the area under study (dry) and soils with a scarcity of organic matter, the prevalence of infectious/parasitic diseases is reduced, thus facilitating the conversion to the organic system. However, this fact should not make veterinarians feel too confident. On the contrary, the knowledge of the veterinarians with regard to animal health management must be improved. Furthermore, health care protocols based on preventive medicine must be developed, and epidemiological data should be part of the veterinary arsenal.

The perspectives for the organic beef cattle sector in the area seem not to be very promising. In fact, the regional census of organic beef cattle farms has decreased rather than increased in recent years [1]. During the interviews, organic farms were also analyzed, and many of their managers conveyed their intention to turn back to the conventional system, due to the difficulty of marketing their product as organic, despite the efforts carried out (transition period, bureaucracy load, etc.).

However, among the organic farms analyzed as a part of the research project (INIA-RTA2009-00122-C03-03 of the Spanish Ministry Economy and Competitiveness), success stories were also found and published by Escribano et al. [25] in their comparative sustainability assessment of extensive beef cattle farms in Dehesas (both conventional and organic ones). In this study, two subgroups of organic farms were identified: (i) a major group of farms that were just certified as organic but did not fatten their calves nor sell them as organic; and (ii) a second group constituted of very well organized full-cycle farms selling organic fattened calves (characterized by belonging to the organic farmers' association, having organic crops and mill, fattening animals, having trucks to transport them, and signing contracts with supermarkets).

Therefore, the advantage for organic beef cattle farmers in the area not belonging to the second group of organic farms (this is a closed group not allowing more farmers to join) is the benefit obtained from greening. However, their low productivity and competitiveness do not allow them to be sustainable, since their unique product was selling recently weaned calves (5-6 months and around $220 \mathrm{~kg}$ live weight) to be fattened either in other farms or in feedlots under the conventional system.

Thus, the domestic market development remains a challenge. In order to improve the contribution of the region to the organic market, structural changes in marketing channels must be made, but this will not be possible if consumers do not increase their demand of organic beef, which is still low due to low purchasing power in the area, the current national financial crisis, and a low level of knowledge and awareness regarding organic products [53]. The fact that regional citizens are used to extensive production systems could also be playing a role, as differences between conventional and organic products are not so clearly observed by the local population, which is the first step in generating demand.

\section{Conclusions}

The GCI data allowed assessing the feasibility of conversion of Dehesa beef cattle farms to the organic system. The integrative approach of the present study allowed taking into account not only the European legal requirements concerning organic farming and its principles, but also the particularities and future challenges of pasture-based beef cattle farms located in semi-arid regions.

The present study has revealed that the farms analyzed must carry out adaptations in all areas of activity that allow them overcome the conversion process successfully, especially with regard to health management and the agro-ecosystem (environmental, ecology principle). Rearing, animal welfare and management issues seem not to be of major concern. However, from the social point of view (principle of fairness), active participation in adding value to the products and on direct sales must be enhanced. In addition, the farms' self-reliance is a key issue in these farms that must be increased, as it would improve the economic results and ecological soundness (nutrients cycling, agro-biodiversity, etc.) of farms. In response to the environmental dimension and the principle of ecology, they should 
implement more environmentally-friendly farming practices (including reduction of total stocking rates, increase of crop area). Finally, transversal support measures are necessary, for example, training consumers' level of awareness regarding organic food and their willingness to pay premium prices.

Acknowledgments: Research funded by project INIA-RTA2009-00122-C03-03 of the Spanish Ministry Economy and Competitiveness. The author thanks the farmers, practitioners and experts that contributed to this research. The author also acknowledges the pre-doctoral financial support of the Fundación Fernando Valhondo Calaff. Special thanks to my Doctoral Thesis supervisors for their guidance (Paula Gaspar, Francisco J. Mesias, Miguel Escribano).

Conflicts of Interest: The author declares no conflict of interest.

\section{References}

1. Magrama 2015. Ministerio de Agricultura, Alimentación y Medio Ambiente. Agricultura Ecológica. Estadísticas 2014. Available online: http:/ / www.magrama.gob.es/es/alimentacion/temas/la-agriculturaecologica/estadisticas_ae_2014_definitivopdf_tcm7-405122.pdf (accessed on 14 March 2016).

2. Nardone, A.; Zervas, G.; Ronchi, B. Sustainability of small ruminant organic systems of production. Livest. Prod. Sci. 2004, 90, 27-39. [CrossRef]

3. Escribano, A.J. Organic livestock farming: Challenges, perspectives, and strategies to increase its contribution to the agrifood system's sustainability. In Organic Farming-A Promising Way of Food Production, 1st ed.; Konvalina, P., Ed.; InTech: Rijeka, Croatia, 2016; pp. 229-260.

4. Benoit, M.; Veysset, P. Conversion of cattle and sheep suckler farming to organic farming: Adaptation of the farming system and its economic consequences. Livest. Prod. Sci. 2003, 80, 141-152. [CrossRef]

5. Blanco-Penedo, I.; López-Alonso, M.; Shore, R.F.; Miranda, M.; Castillo, C.; Hernández, J.; Benedito, J.L. Evaluation of organic, conventional and intensive beef farm systems: Health, management and animal production. Animal 2012, 6, 1503-1511. [CrossRef] [PubMed]

6. European Commission. EEC Council Directive 92/43/EEC of 21 May 1992 on the Conservation of Natural Habitats and of Wild Fauna and Flora. 1992. Available online: http:/ /ec.europa.eu/environment/nature/ legislation/habitatsdirective/index_en.htm (accessed on 14 March 2016).

7. Moreno, G.; Pulido, F.J. The functioning, management and persistence of Dehesas. In Agroforestry in Europe: Current Status and Future Prospects, 1st ed.; Rigueiro-Rodríguez, A., McAdam, J., Mosquera-Losado, M., Eds.; Springer Science + Business Media B.V.: Dordrecht, The Netherlands, 2009; pp. 127-160.

8. Sánchez, J. Las macromagnitudes agrarias. In La Agricultura y la Ganadería Extremeñas. Informe 2012; Facultad de Ciencias Económicas y Empresariales/Escuela de Ingenierías Agrarias, Universidad de Extremadura, Caja de Badajoz: Badajoz, Spain, 2013; pp. 37-52.

9. Easdale, M.H.; Aguiar, M.R. Regional forage production assessment in arid and semi-arid rangelands-A step towards social-ecological analysis. J. Arid Environ. 2012, 83, 35-44. [CrossRef]

10. Peacock, C.; Sherman, D.M. Sustainable goat production-Some global perspectives. Small Rumin. Res. 2010, 89, 70-80. [CrossRef]

11. Prudencio, C. El mercado de trabajo. In La Agricultura y Ganadería Extremeña. Informe 2012; Facultad de Ciencias Económicas y Empresariales/Escuela de Ingenierías Agrarias, Universidad de Extremadura, Caja de Badajoz: Badajoz, Spain, 2013; pp. 266-270.

12. Marsden, T.; Banks, J.; Bristow, G. The social management of rural nature: Understanding agrarian-based rural development. Environ. Plan. A 2002, 34, 809-825. [CrossRef]

13. Pretty, J. Agriculture: Reconnecting People, Land and Nature; Earthscan: London, UK, 2002; p. 261.

14. Boyazoglu, J.; Hatziminaoglou, I.; Morand-Fehr, P. The role of the goat in society: Past, present and perspectives for the future. Small Rumin. Res. 2005, 60, 13-23. [CrossRef]

15. De Rancourt, M.; Fois, N.; Lavín, M.P.; Tchakérian, E.; Vallerand, F. Mediterranean sheep and goats production: An uncertain future. Small Rumin. Res. 2006, 62, 167-179. [CrossRef]

16. Cocca, G.; Sturaro, E.; Gallo, L.; Ramanzin, M. Is the abandonment of traditional livestock farming systems the main driver of mountain landscape change in Alpine areas? Land Use Pol. 2012, 29, 878-886. [CrossRef]

17. MacDonald, D.; Crabtree, J.R.; Wiesinger, G.; Dax, T.; Stamou, N.; Fleury, P.; Lazpita, J.G.; Gibon, A. Agricultural abandonment in mountain areas of Europe: Environmental consequences and policy response. J. Environ. Manag. 2000, 59, 47-69. [CrossRef] 
18. Gellrich, M.; Baur, P.; Koch, B.; Zimmermann, N.E. Agricultural land abandonment and natural forest re-growth in the Swiss mountain: A spatially explicit economic analysis. Agric. Ecosyst. Environ. 2007, 118, 93-108. [CrossRef]

19. Gaspar, P.; Mesías, F.J.; Escribano, M.; Pulido, F. Sustainability in Spanish extensive farms (Dehesas): An economic and management indicator-based evaluation. Rangel. Ecol. Manag. 2009, 62, 153-162. [CrossRef]

20. Franco, J.A.; Gaspar, P.; Mesías, F.J. Economic analysis of scenarios for the sustainability of extensive livestock farming in Spain under the CAP. Ecol. Econ. 2012, 74, 120-129. [CrossRef]

21. Escribano, A.J.; Gaspar, P.; Mesias, F.J.; Pulido, A.F.; Escribano, M. A sustainability assessment of organic and conventional beef cattle farms in agroforestry systems: The case of the Dehesa rangelands. ITEA 2014, 110, 343-367. [CrossRef]

22. Mena, Y.; Nahed, J.; Ruiz, F.A.; Sánchez-Muñoz, J.B.; Ruiz-Rojas, J.L.; Castel, J.M. Evaluating mountain goat dairy systems for conversion to the organic model, using a multicriteria method. Animal 2012, 6, 693-703. [CrossRef] [PubMed]

23. Toro-Mújica, P.; García, A.; Gómez-Castro, A.G.; Acero, R.; Perea, J.; Rodríguez-Estévez, V.; Aguilar, C.; Vera, R. Technical efficiency and viability of organic dairy sheep farming systems in a traditional area for sheep production in Spain. Small Rumin. Res. 2011, 100, 89-95. [CrossRef]

24. Toro-Mújica, P.; García, A.; Gómez-Castro, A.; Perea, J.; Rodríguez-Estévez, V.; Angón, E.; Barba, C. Organic dairy sheep farms in south-central Spain: Typologies according to livestock management and economic variables. Small Rumin. Res. 2012, 104, 28-36. [CrossRef]

25. Escribano, A.J.; Gaspar, P.; Mesías, F.J.; Escribano, M.; Pulido, F. Comparative sustainability assessment of extensive beef cattle farms in a high nature value agroforestry system. In Rangeland Ecology, Management and Conservation Benefits, 1st ed.; Squires, V.R., Ed.; Nova Publishers: New York, NY, USA, 2015; pp. 65-85.

26. IFOAM. Principles of Organic Agriculture. International Federation of Organic Agriculture Movements. 2005. Available online: http:/ /www.ifoam.org/en/organic-landmarks/principles-organic-agriculture (accessed on 22 January 2016).

27. The Council of the European Union. Council Regulation (EC) No. 834/2007 of 28 June 2007 on organic production and labelling of organic products and repealing Regulation (ECC) No. 2092/91. Off. J. Eur. Union 2007, 50, 1-23.

28. Mena, Y.; Nahed, J.; Ruiz, F.A.; Castel, J.M.; Ligero, M. Proximity to the organic model of dairy goat systems in the Andalusian Mountains (Spain). Trop. Subtrop. Agroecosyst. 2009, 11, 69-73.

29. Nahed-Toral, J.; Sanchez-Munoz, B.; Mena, Y.; Ruiz-Rojas, J.; Aguilar-Jimenez, R.; Castel, J.M.; de Asis Ruiz, F.; Orantes-Zebadua, M.; Manzur-Cruz, A.; Cruz-Lopez, J.; et al. Potential for conversion of agrosilvopastoral systems of dairy cattle to the organic production model in southern eastern Mexico. J. Anim. Vet. Adv. 2012, 11, 3081-3093. [CrossRef]

30. Nahed-Toral, J.; Sánchez-Muñoz, B.; Mena, Y.; Ruiz-Rojas, J.; Aguilar-Jimenez, R.; Castel, J.M.; de Asis Ruiz, F.; Orantes-Zebadua, M.; Manzur-Cruz, A.; Cruz-López, J.; et al. Feasibility of converting agrosilvopastoral systems of dairy cattle to the organic production model in south eastern Mexico. J. Clean. Prod. 2013, 43, 136-145. [CrossRef]

31. Boatto, V.; Trestini, S. The role of post-2013 common agricultural policy on the sustainability of Italian beef production. Agric. Conspec. Sci. 2013, 78, 137-141.

32. The European Parliament and the Council of the European Union. Regulation (EU) No 1306/2013 of the European Parliament and of the Council of 17 December 2013 on the Financing, Management and Monitoring of the Common Agricultural Policy and Repealing Council Regulations (EEC) No 352/78, (EC) No 165/94, (EC) No 2799/98, (EC) No 814/2000, (EC) No 1290/2005 and (EC) No 485/2008. Available online: http:/ / eur-lex.europa.eu/legal-content/EN/ALL/?uri=celex:32013R1306 (accessed on 16 June 2016).

33. Wittman, H.; Becky, M.; Hergesheimer, C. Linking local food systems and the social economy? Future roles for farmers' markets in Alberta and British Columbia. Rural Soc. 2012, 77, 36-61. [CrossRef]

34. Leach, T.; Baret, P.V.; Stilmant, D. Sustainability indicators for livestock farming. A review. Agron. Sustain. Dev. 2013, 33, 311-327. [CrossRef]

35. Nahed, J.; Castel, J.M.; Mena, Y.; Caravaca, F. Appraisal of the sustainability of dairy goat systems in Southern Spain according to their degree of intensification. Livest. Sci. 2006, 101, 10-23. [CrossRef] 
36. Ripoll-Bosch, R.; Díez-Unquera, B.; Ruiz, R.; Villalba, D.; Molina, E.; Joy, M.; Olaizola, A.; Bernués, A. An integrated sustainability assessment of Mediterranean sheep farms with different degrees of intensification. Agric. Syst. 2012, 105, 46-56. [CrossRef]

37. Kerselaers, E.; Cock, L.D.; Lauwers, L.; Huylenbroeck, G.V. Modelling farm-level economic potential for conversion to organic farming. Agric. Syst. 2007, 94, 671-682. [CrossRef]

38. Masera, O.; Astier, S.; López-Ridaura, S. Sustentabilidad y manejo de los recursos naturales. In El Marco de Evaluación MESMIS, 1st ed.; Masera, O., Astier, S., López-Ridaura, S., Eds.; Mundi-Prensa, IE-UNAM: Mexico, 1999; p. 160.

39. Ten Brink, B.J.E.; Hosper, S.H.; Colin, F. A quantitative method for description and assessment of ecosystems: The AMOEBA approach. Mar. Pollut. Bull. 1991, 23, 265-270. [CrossRef]

40. Astier, M.; García-Barrios, L.; Galván-Miyoshi, Y.; González-Esquivel, C.E.; Masera, O.R. Assessing the Sustainability of Small Farmer Natural Resource Management Systems. A Critical Analysis of the MESMIS Program (1995-2010). Ecol. Soc. 2012, 17, 25. [CrossRef]

41. Hair, J.F.; Anderson, R.F.; Tathakm, R.L.; Black, W.C. Análisis Multivariante, 5th ed.; Hair, J.F., Anderson, R.E., Tatham, R.L., Eds.; Prentice Hall Iberia: Madrid, Spain, 1999; p. 832.

42. SPSS (Statistical Package for the Social Sciences). Manual del Usuario del Sistema Básico de IBM SPSS Statistics 21; IBM Corporation: Armonk, NY, USA, 2012; p. 464.

43. Ripoll-Bosch, R.; Joy, M.; Bernués, A. Role of self-sufficiency, productivity and diversification on the economic sustainability of farming systems with autochthonous sheep breeds in less favoured areas. Animal 2013, 4, 1-9. [CrossRef] [PubMed]

44. The Commission of the European Communities. Commission Regulation (EC) No. 889/2008 Laying down Detailed Rules for the Implementation of Commission Regulation (EC) No. 834/2007 on Organic Production and Labelling of Organic Products with Regard to Organic Production, Labelling and Control. Available online: http:/ / eur-lex.europa.eu/LexUriServ/LexUriServ.do?uri=OJ:L:2008:250:0001:0084:en:PDF (accessed on 16 June 2016).

45. Dantsis, T.; Loumou, A.; Giourga, C. Organic agriculture's approach towards sustainability; its relationships with the agro-industrial complex, a case study in Central Macedonia, Greece. J. Agric. Environ. Ethics 2009, 22, 197-216. [CrossRef]

46. Andriarimalala, J.H.; Rakotozandriny, J.N.; Andriamandroso, A.L.H.; Penot, E.; Naudin, K.; Dugué, P.; Tillard, E.; Decruyenaere, V.; Salgado, P. Creating synergies between conservation agriculture and cattle production in crop-livestock farms: A study case in the lake Alaotra region of Madagascar. Exp. Agric. 2013, 49, 352-365. [CrossRef]

47. Sanderson, M.A.; Archer, D.; Hendrickson, J.; Kronberg, S.; Liebig, M.; Nichols, K.; Schmer, M.; Tanaka, D.; Aguilar, J. Diversification and ecosystem services for conservation agriculture: Outcomes from pastures and integrated crop-livestock systems. Renew. Agric. Food Syst. 2013, 28, 129-144. [CrossRef]

48. Hrabalová, A.; Zander, K. Organic beef farming in the Czech Republic: Structure, development and economic performance. Agric. Econ. Czech 2006, 52, 89-100.

49. Tzouramani, I.; Sintori, A.; Liontakis, A.; Karanikolas, P.; Alexopoulos, G. An assessment of the economic performance of organic dairy sheep farming in Greece. Livest. Sci. 2011, 141, 136-142. [CrossRef]

50. Argyropoulos, C.; Tsiafouli, M.A.; Sgardelis, S.P.; Pantis, J.D. Organic farming without organic products. Land Use Pol. 2013, 32, 324-328. [CrossRef]

51. The World of Organic Agriculture. Statistics \& Emerging Trends; FIBL \& IFOAM: Rheinbreitbach, Switzerland, 2016; p. 333. Available online: https://shop.fibl.org/fileadmin/documents/shop/1698-organic-world-2016. pdf (accessed on 16 June 2016).

52. Lobley, M.; Butler, A.; Reed, M. The contribution of organic farming to rural development: An exploration of the socio-economic linkages of organic and non-organic farms in England. Land Use Pol. 2009, 26, 723-735. [CrossRef]

53. García-Torres, S.; López-Gajardo, A.; Mesías, F.J. Intensive vs. free-range organic beef. A preference study through consumer liking and conjoint analysis. Meat Sci. 2016, 114, 114-120. [CrossRef]

(C) 2016 by the author; licensee MDPI, Basel, Switzerland. This article is an open access article distributed under the terms and conditions of the Creative Commons Attribution (CC-BY) license (http:/ / creativecommons.org/licenses/by/4.0/). 